\title{
Effect of Premolar Extraction and Incisor Retraction on the Soft Tissue in Adult Skeletal Open Bite Subjects Treated With Miniplate Anchored Intrusion of Maxillary Posterior Teeth
}

\author{
Eiman S. Marzouk ${ }^{1}$, Hassan E. Kassem²
}

\section{ABSTRACT:}

Objective: This study was conducted to determine the effect of premolar extraction and incisor retraction on the soft tissue profile of skeletal open bite adults following maxillary posterior teeth intrusion. Materials and Methods: Lateral cephalometric radiographs of 28 adults with skeletal open bite (age $=22.6 \pm 2.1$ years) were taken following molar intrusion with zygomatic miniplate skeletal anchorage and after four first premolars extraction. Several soft tissue variables were measured. Correlations, mean ratios and regression equations between the change in lip position and incisor retraction were calculated. Results:Both the upper and lower lips moved backwards by $3.46 \mathrm{~mm} \pm 0.84 \mathrm{~mm}$ ( $\mathrm{P} \leq 0.01$ ) and $0.87 \mathrm{~mm} \pm 0.23 \mathrm{~mm}(\mathcal{P} \leq 0.05)$ respectively, with a significant reduction in the angle of convexity by $1.36^{\circ} \pm 0.24^{\circ}(\mathcal{P} \leq 0.05)$. Strong correlations were found between the amount of upper incisor retraction and backward movement of the upper lip with a mean ratio of 1.04:1 $(r=0.812, \mathbb{P} \leq 0.01)$ and with the reduction of soft tissue convexity angle with a mean ratio of 2.65:1 $(r=0.814, \mathbb{P} \leq 0.01)$ and between the lower incisor retraction and backward movement of the lower lip with a mean ratio of 0.76:1 $(r=0.802, \mathcal{P} \leq 0.01)$. Conclusion: The pattern of change in soft tissue profile in this study was similar to studies of premolar extraction without prior molar intrusion. However, the ratio of change of upper lip position relative to the upper incisor retraction was higher compared to ratios reported in the literature which may be attributed to the underlying long face skeletal pattern.

Keywords: Premolar extraction, incisor retraction, soft tissue profile, skeletal anchorage, intrusion, cephalometrics.

\section{INTRODUCTION}

Premolar extraction has been part of the orthodontic armamentarium even before Edward Angle started "the new school of orthodontia". ${ }^{1}$ Clinicians may still choose to extract premolars for the resolution of crowding, correcting the torque of the incisors, particularly the maxillary incisors and the reduction of profile fullness. ${ }^{2}$

The effect of orthodontic treatment on the position of the upper and lower lips following premolar extraction has been debated considerably in the orthodontic literature. ${ }^{3-15}$ Extraction therapy was typically associated with the retraction of the upper and lower lip. ${ }^{3,4,12}$ The popular assumption that extraction therapy would result in undesirable flattened dished-in faces has been disproven by many studies. ${ }^{11,13-15}$

Large individual variations in lip response following extraction of upper first premolars were found to be highly inconstant. ${ }^{10}$ Aside of treatment modalities, other factors come to play

1- Lecturer, Department of Orthodontics, Faculty of Dentistry, Alexandria University, Egypt.

2- Lecturer, Department of Orthodontics, Faculty of Dentistry, Alexandria University, Egypt. 
including: age, gender, in addition to dental, skeletal and soft tissue patterns at the start of treatment. ${ }^{16}$ There is paucity in the literature whether or not the vertical pattern of the face affects the response of soft tissue to incisor retraction.

Anterior open bite with posterior vertical maxillary excess has always been a puzzling orthodontic difficulty especially in adult subjects, where orthognathic surgery has been the solution to achieve good facial esthetics. ${ }^{17-19}$ The appearance of skeletal anchorage offered a non-surgical option for the correction of this dentofacial deformity. Several studies have reported successful treatment of such cases by intruding maxillary and/or mandibular posterior segments using miniplate and miniscrew anchorage. ${ }^{20-29}$ A recent systematic review has summarized the studies conducted on this subject. ${ }^{30}$

Deguchi et al. $^{27}$ studied the effect of molar intrusion followed by premolar extraction on several soft tissue parameters. However, the isolated effect of premolar extraction and incisor retraction on the upper and lower lips following maxillary molar intrusion has not been discriminately reported. Presuming the soft tissue response of long face patients to incisor retraction differ from the average values, this begs the question how the soft tissue of long face subjects treated by molar intrusion to a more average vertical pattern would respond to premolar extraction.

Hence, our objective was to study the changes of the soft tissue profile following premolar extraction and incisor retraction in a sample of adult openbite subjects treated with maxillary posterior teeth intrusion using zygomatic miniplate anchorage. Mean ratios and regression equations between incisor retraction and soft tissue changes can help the clinician predict changes in this patient cohort.

\section{MATERIALS AND METHODS}

Twenty-Eight adult patients (19-28 years) were recruited for the primary study. The sample size estimation was calculated based on the change in the amount of molar intrusion. ${ }^{29}$
The selection criteria included patients with 3 to $8 \mathrm{~mm}$ anterior open bite measured on lateral cephalometric radiograph with either Angle Class I or Class II malocclusion. According to Burstone analysis $^{31}$, all subjects presented with posterior vertical maxillary dento-alveolar excess. This research was conducted in the Department of Orthodontics, Alexandria University, Egypt. Each patient was asked to sign an informed consent before enrollment. The protocol of the study was approved by the Ethical Committee of the Institutional Review Board of Research, Faculty of Dentistry, Alexandria University, Egypt.

The clinical procedures used in this study were formerly reported. ${ }^{29}$ Following alignment of the maxillary teeth in three segments, a banded double transpalatal arch was cemented to the maxillary premolars and permanent molars. The maxillary buccal segments were intruded using NiTi coil springs (450 g per side) attached to titanium miniplates inserted bilaterally in the lower surface of the zygomatic buttress. When the overbite reached 1-2 mm, the buccal segments were tied to the miniplates by stainless steel ligatures.

Subsequently, four first premolars were extracted. Extraction was postponed till after the intrusion to ascertain the need for extraction and determine the anchorage requirements that may be affected by subsequent auto-rotation of the mandible following molar intrusion. Extractions were performed to correct the long axis of the upper incisors, reduce the over jet and to resolve lower anterior crowding. The upper and lower arches were relieved with 0.014 - in or 0.016- in NiTi wires followed by 0.019 x $0.025-$ in NiTi wire. En masse retraction was done on $0.019 \times 0.025$ - in stainless steel wires. The anterior teeth were ligated together using stainless steel ligature to consolidate the anterior segment. Nickel titanium coil springs delivering 200g were 
stretched between the canines and the first molars. During leveling and alignment as well as en masse retraction the manipulates were tied to the first maxillary molars to maintain the intrusion and to act as indirect anchorage when needed. When antero-posterior movement of the maxillary molars was needed according to the anchorage requirements, the plates were tied to the arch wire instead.

Lateral cephalograms of the subjects after maxillary posterior segment intrusion and at the end of the treatment were done with the same machine, with the teeth in maximal inter cuspation and the lips lightly touching. ${ }^{32}$ Landmarks and planes used in this study are shown in Figure 1. Linear variables were measured to a Horizontal Reference Line (HRL) drawn through point $\mathrm{S}$ at $7^{\circ}$ to $\mathrm{SN}$, and Vertical Reference line (VRL) perpendicular to HRL passing through point S. Angular and linear measurements are shown in Figures 2 and 3.

\section{STATISTICAL ANALYSIS}

To test for reliability, both investigators traced and measured ten randomly selected radiographs. Measurements by the first investigator were done at least 2 weeks after the first measurements. Paired sample $t$ tests showed no significant difference between the first and second sets of measurements of the same examiner and between the measurements of the first and second investigator. Intra-rater and inter-rater intra class correlation coefficients were greater than 0.84 and greater than 0.79, respectively. Histograms and Shapiro-wilk tests were used to verify the normality of the data. Paired t tests were used to compare cephalometric variables before and after premolar extraction. Correlation coefficients, mean ratios and linear regression equations between the change of the horizontal position of the incisors and several soft tissue variables were calculated. Statistical Package for the Social Science (SPSS, Version 20) was used for statistical analysis. Significance level was set at $\mathrm{P} \leq 0.05$.

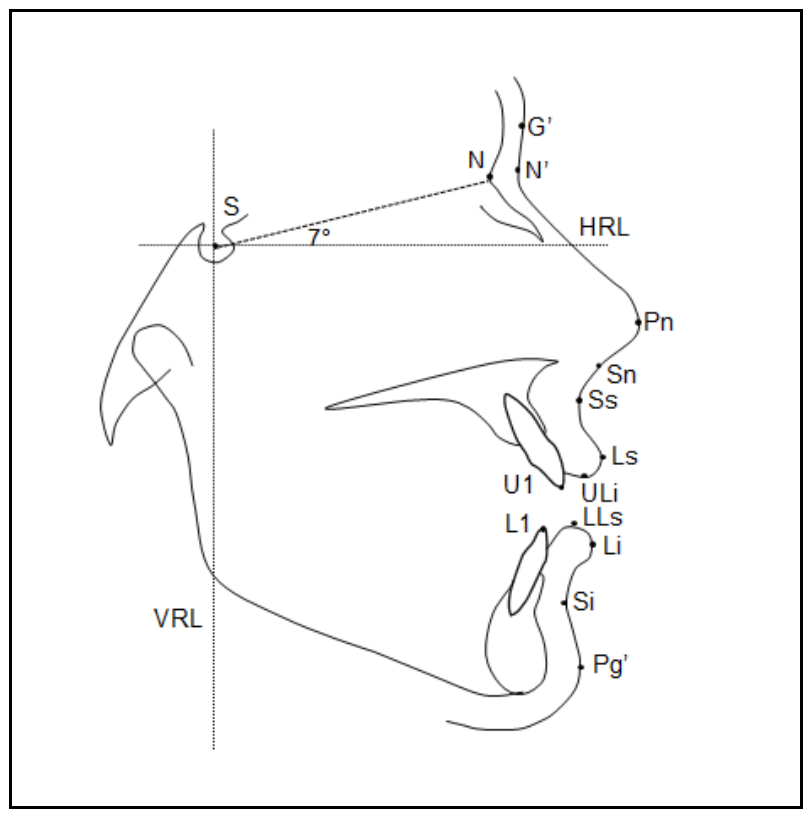

Figure 1. Landmarks and reference planes. S, sella; $\mathrm{N}$, nasion; N', soft tissue nasion; G', soft tissue glabella; Pn, pronasale; Sn, subnasale; Ss, sulcus superius; Ls, labraele superius; ULi, upper lip inferius; LLs, lower lip superius; Li, labrale inferius; Si, sulcus inferius; Pg', soft tissue pogonion; HRL, horizontal reference line; VRL, vertical reference line.

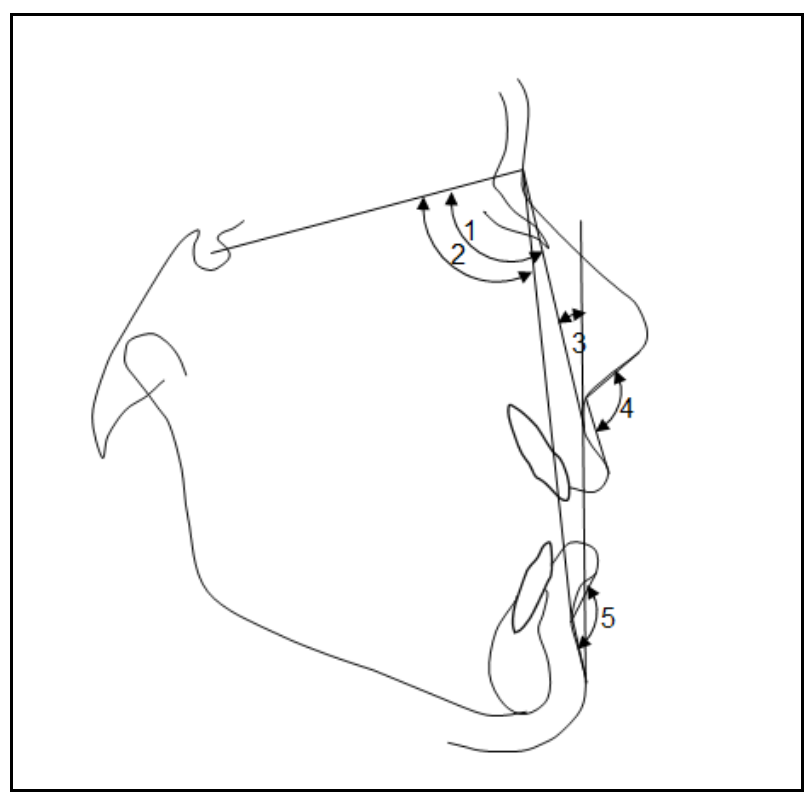

Figure 2. Angular measurements. 1, SN'A' angle (S-N'/N'-Ss); 2, SN'B' angle (S-N'/N'-Si.); 3, Soft tissue convexity $\left(180^{\circ}-\angle \mathrm{N}^{\mathrm{x}} \mathrm{SsPg}_{\mathrm{g}}^{\prime}\right) ; 4$, Nasolabial angle (NLab); 5, Mentolabial angle (MLab). 


\section{Egyptian \\ Orthodontic Journal}

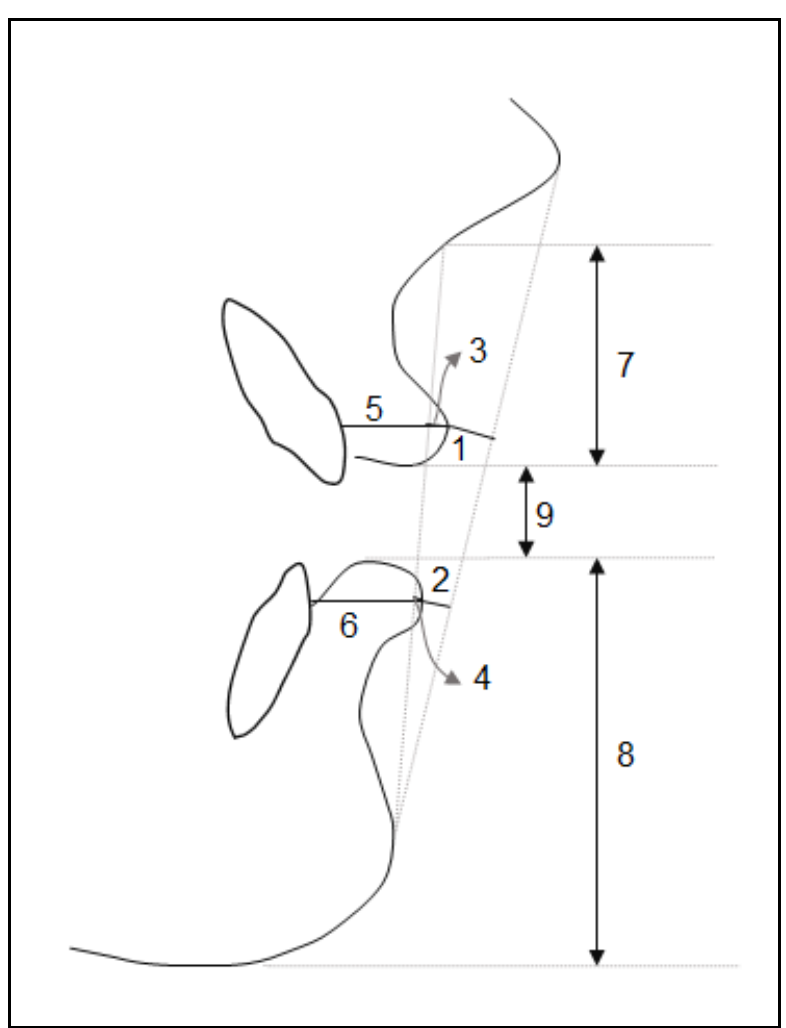

Figure 3. Linear measurements. 1, Upper lip to E-line (Ls-PnPg'); 2, Lower lip to E-line (Li-PnPg'); 3, Upper lip to Burstone's plane (Ls-SnPg'); 4, Lower lip to Burstone's plane (Li-SnPg'); 5, Upper lip thickness (ULT); 6, Lower lip thickness (LLT); 7, Upper lip length (ULL); 8, Lower lip length (LLL); 9, Interlabial gap.

\section{RESULTS}

Lateral cephalometric radiographs for all 28 patients were available for this analysis. The mean age at the start of treatment was 22.6 years \pm 2.1 years with an age range of 19.3 years to 26.9 years. The study sample consisted of 28 patients (16 women, 12 men), 17 Angle Class I and 11 Angle Class II. All the subjects recruited for the primary study had long facial heights (N-S-Gn angle: $77.09^{\circ} \pm 3.01^{\circ}$, SN-MP angle: $49.05^{\circ} \pm 3.90^{\circ}$, ANS-Me (mm): $78.05 \mathrm{~mm} \pm 5.83 \mathrm{~mm}$ and N-Me (mm): $124.68 \mathrm{~mm} \pm 6.14 \mathrm{~mm}){ }^{29}$ Cephalometric measurements before and after premolar extraction and mean differences are shown in Table 1.

The upper incisors were retracted $5.37^{\circ} \pm 1.5^{\circ}$ $(\mathrm{P} \leq 0.01)$ and $3.6 \mathrm{~mm} \pm 0.78 \mathrm{~mm}(\mathrm{P} \leq 0.05)$. The long axis of the lower incisors and their horizontal position did not change significantly. The effects of incisor retraction were noticed in the significant reduction of SN'A' angle $\left(1.65^{\circ} \pm 0.34^{\circ}, \mathrm{P} \leq 0.01\right)$, SNA angle $\left(1.72^{\circ} \pm 0.54^{\circ}, \mathrm{P} \leq 0.01\right)$, the angle of convexity $\left(1.36^{\circ} \pm 0.24^{\circ}, \mathrm{P} \leq 0.05\right)$, and the interlabial gap $(0.8 \mathrm{~mm} \pm 0.17 \mathrm{~mm}, \mathrm{P} \leq 0.05)$ (Table 1$)$.

Both the upper and lower lips moved backwards by $3.46 \mathrm{~mm}$ (SD, $0.84 \mathrm{~mm}, \mathrm{P} \leq 0.01$ ) and $0.87 \mathrm{~mm}(\mathrm{SD}, 0.23 \mathrm{~mm}, \mathrm{P} \leq 0.05)$ relative to the VRL and $1.52 \mathrm{~mm}(\mathrm{SD}, 0.28 \mathrm{~mm}, \mathrm{P} \leq 0.05)$ and $0.76 \mathrm{~mm}(\mathrm{SD}, 0.15 \mathrm{~mm}, \mathrm{P} \leq 0.05)$ relative to $\mathrm{E}$ line, respectively. Additionally, both the upper and lower lips increased in length by $1.15 \mathrm{~mm}(\mathrm{SD}, 0.37 \mathrm{~mm}, \mathrm{P} \leq 0.05)$ and $0.50 \mathrm{~mm}$ (SD, $0.14 \mathrm{~mm}, \mathrm{P} \leq 0.05$ ), and thickness by $1.04 \mathrm{~mm}$ (SD, $0.24 \mathrm{~mm}, \mathrm{P} \leq 0.05$ ) and $0.56 \mathrm{~mm}$ ( $\mathrm{SD}, 0.15 \mathrm{~mm}, \mathrm{P} \leq 0.05$ ), respectively. A significant increase was found in the vertical position of the upper lip $(1.35 \mathrm{~mm} \pm 0.22 \mathrm{~mm}, \mathrm{P} \leq 0.01)$. Moreover, there was a significant backward movement of the upper lip sulcus by $3.45 \mathrm{~mm}$ (SD, $0.51 \mathrm{~mm}, \mathrm{P} \leq 0.01)$. Both the nasolabial angle $\left(2.8^{\circ} \pm 0.87^{\circ}, \mathrm{P} \leq 0.01\right)$ and mentolabial angle $\left(2.62^{\circ} \pm 0.48^{\circ}, \mathrm{P} \leq 0.01\right)$ became more obtuse (Table 1).

Table 2 shows the mean ratios, regression equations and correlation coefficients between incisor retraction and soft tissue changes. Several strong correlations were found between the change in the incisor position and several soft tissue variables. The maxillary incisor retraction and upper lip retraction showed a strong positive correlation $(r=0.812, P \leq 0.01)$, with a mean ratio of $1.04: 1$. The mean ratio of upper incisor retraction with the reduction of soft tissue convexity angle was 2.65:1 $(r=0.814, P \leq 0.01)$.

Statistically significant strong negative correlation was found between the maxillary incisor retraction and the change in the vertical position of the upper lip $(r=-0.781, P \leq 0.01)$ as well as the change of the upper lip length $(r=-0.804, P \leq 0.01)$ with mean ratios of 2.67:1 and 3.13:1, respectively. Moreover, the mandibular incisor retraction showed statistically significant strong correlation with the retraction of the lower lip $(r=0.802, P \leq 0.01)$ with a mean ratio of $0.76: 1$.

Representative lateral cephalometric radiographs following intrusion before and after premolar extraction are shown in Figure 4. 
Egyptian

Orthodontic Journal

Table 1. Cephalometric measurements and mean differences before (T1) and after (T2) premolar extraction.

\begin{tabular}{|c|c|c|c|c|c|c|c|}
\hline & \multicolumn{2}{|c|}{ T1 } & \multicolumn{2}{|c|}{$\mathbf{T} 2$} & \multicolumn{3}{|c|}{ T2-T1 } \\
\hline & Mean & SD & Mean & SD & Mean & SD & $\boldsymbol{P}$ \\
\hline Ls-E (mm) & 0.77 & 0.53 & -0.75 & 0.8 & -1.52 & 0.28 & $*$ \\
\hline Li-E (mm) & 2.56 & 0.36 & 1.8 & 0.30 & -0.76 & 0.15 & $*$ \\
\hline Ls-Sn-Pg' $\left({ }^{\circ}\right)$ & 7.5 & 0.81 & 6.04 & 1.07 & -1.46 & 0.37 & $*$ \\
\hline Li-Sn-Pg' $\left({ }^{\circ}\right)$ & 7.67 & 0.60 & 6.94 & 0.61 & -0.73 & 0.18 & $*$ \\
\hline ULT (mm) & 14.51 & 0.77 & 15.55 & 0.81 & 1.04 & 0.24 & $*$ \\
\hline LLT (mm) & 16.2 & 1.03 & 16.76 & 0.98 & 0.56 & 0.15 & $*$ \\
\hline ULL (mm) & 24.25 & 0.95 & 25.40 & 0.86 & 1.15 & 0.37 & $*$ \\
\hline LLL (mm) & 43.62 & 1.37 & 44.12 & 1.37 & 0.50 & 0.14 & $*$ \\
\hline Ss-VRL (mm) & 81.49 & 1.05 & 78.04 & 1.36 & -3.45 & 0.51 & $* *$ \\
\hline Ls-VRL (mm) & 85.04 & 1.06 & 81.58 & 1.23 & -3.46 & 0.84 & $* *$ \\
\hline Li-VRL (mm) & 83.22 & 1.15 & 82.35 & 1.06 & -0.87 & 0.23 & $*$ \\
\hline Si-VRL (mm) & 74.52 & 1.19 & 73.99 & 1.16 & -0.53 & 0.13 & NS \\
\hline ULi-HRL (mm) & 64.81 & 1.13 & 66.16 & 1.07 & 1.35 & 0.22 & $* *$ \\
\hline LLs-HRL (mm) & 67.19 & 1.21 & 66.71 & 1.19 & -0.48 & 0.23 & NS \\
\hline Interlabial gap (mm) & 0.99 & 0.18 & 0.19 & 0.11 & -0.80 & 0.17 & $*$ \\
\hline SN'A' $\left({ }^{\circ}\right)$ & 84.69 & 2.35 & 83.04 & 2.49 & -1.65 & 0.34 & $* *$ \\
\hline SN'B' $\left({ }^{\circ}\right)$ & 80.15 & 2.8 & 80.09 & 2.64 & 0.06 & 0.05 & NS \\
\hline Soft tissue convexity $\left({ }^{\circ}\right)$ & 14.56 & 0.55 & 13.24 & 0.63 & -1.36 & 0.24 & $*$ \\
\hline Nlab $\left(^{\circ}\right)$ & 101.12 & 6.22 & 103.92 & 6.14 & 2.8 & 0.87 & $* *$ \\
\hline Mlab $\left(^{\circ}\right)$ & 131.44 & 3.03 & 134.06 & 3.10 & 2.62 & 0.48 & $* *$ \\
\hline U1-VRL (mm) & 70.79 & 5.59 & 67.19 & 5.35 & -3.6 & 0.78 & $*$ \\
\hline L1-VRL (mm) & 67.77 & 4.16 & 67.11 & 4.03 & -0.66 & 0.11 & NS \\
\hline SNA $\left({ }^{\circ}\right)$ & 81.92 & 2.26 & 80.20 & 2.62 & -1.72 & 0.54 & $* *$ \\
\hline SNB $\left({ }^{\circ}\right)$ & 77.3 & 2.74 & 77.18 & 3.23 & -0.12 & 0.06 & NS \\
\hline U1-HRL( $\left.{ }^{\circ}\right)$ & 117.1 & 2.79 & 111.73 & 1.28 & -5.37 & 1.5 & $* *$ \\
\hline L1-MP $\left(^{\circ}\right)$ & 91.21 & 2.66 & 90.03 & 1.06 & -1.18 & 0.32 & NS \\
\hline
\end{tabular}

Negative values represent decreases during treatment; positive values represent increases during treatment.

$* P \leq 0.05 ; * * P \leq 0.01 ; \mathrm{NS}$, not significant.

Table 2. Mean ratios, regression equations and correlation coefficients between incisor retraction and the change in selected soft tissue variables.

\begin{tabular}{|l|c|c|c|c|}
\hline Variable 1 & Variable 2 & Mean Ratio & Regression equations $\dagger$ & $\boldsymbol{r} \neq$ \\
\hline U1-VRL & Ls-VRL & $-1.04:-1$ & 0.74 U1-VRL -0.82 & $0.812^{*}$ \\
\hline U1-VRL & Soft tissue convexity & $-2.65:-1$ & 0.12 U1-VRL -0.938 & $0.814^{*}$ \\
\hline U1-VRL & ULi-HRL & $-2.67: 1$ & -0.18 U1-VRL + 0.70 & $-0.781^{*}$ \\
\hline U1-VRL & ULL & $-3.13: 1$ & -0.23 U1-VRL +0.32 & $-0.804^{*}$ \\
\hline L1-VRL & Li-VRL & $-0.76:-1$ & 1.62 L1-VRL + 0.19 & $0.802^{*}$ \\
\hline
\end{tabular}

† Variable 2 = B x Variable 1 + constant

$\ddagger$ Pearson correlation coefficient

* $P \leq 0.01$ 

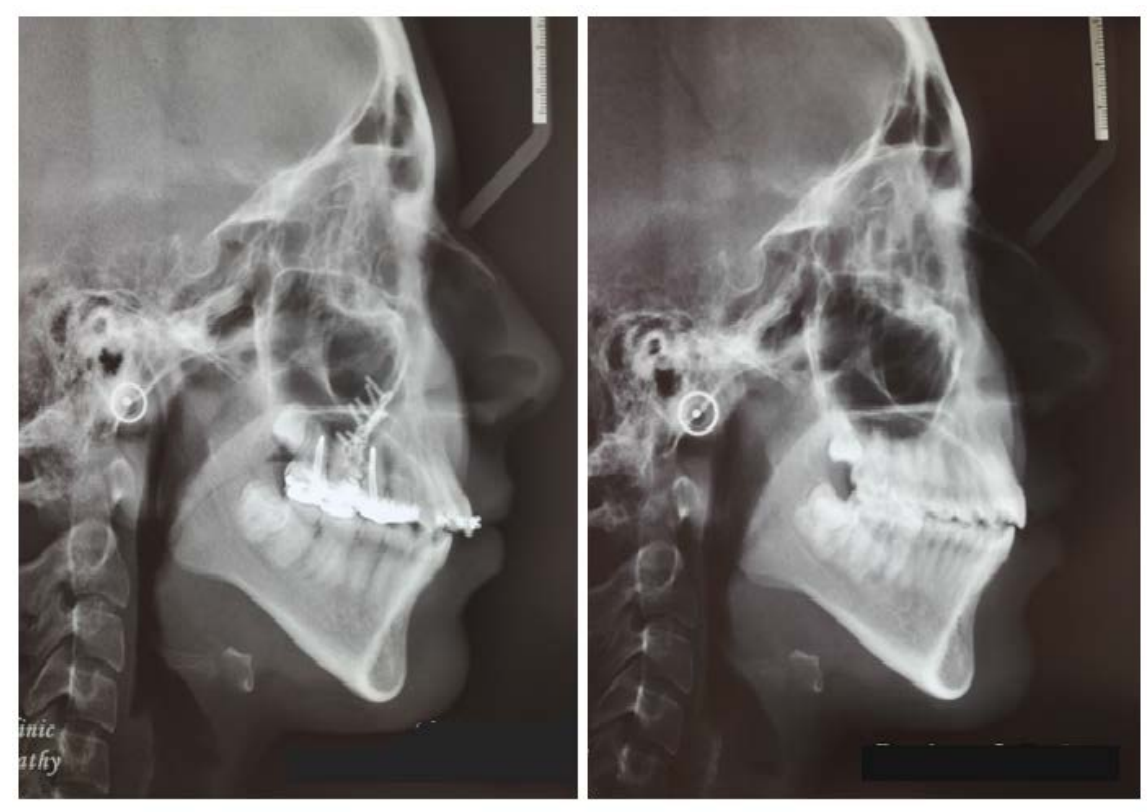

Figure 4. Lateral cephalograms following intrusion before and after premolar extraction.

\section{DISCUSSION}

The present report describes the effect of premolar extraction and incisor retraction on the upper and lower lips following maxillary posterior teeth intrusion with zygomatic miniplate anchorage in skeletal open bite adult subjects. The objective of this report was to derive ratios and regression equations to enable the clinician to predict the change in the soft tissue of long face patients who need premolar extraction following intrusion of maxillary posterior teeth. This is based on the assumption that the soft tissues of subjects with different skeletal patterns will respond differently to incisor retraction. Currently, dental software as the Dolphin imaging software offers the operator the possibility of adjusting skeletal to soft tissue movement ratios. ${ }^{33}$

The caveat with this cohort of patients is that their original long face skeletal pattern with associated characteristics of the soft tissue has been altered by maxillary posterior teeth intrusion. The question was whether these patients will react according to the pretreatment skeletal pattern or the more normalized pattern following intrusion. Details of the primary study were reported in an earlier publication. ${ }^{29}$

The sample size was calculated based on the primary outcome of the original study, i.e. molar intrusion. This may raise the question whether this ancillary report has enough power to find difference in its outcomes. However, it was stated that sample sizes greater than 25 have a reasonable chance of detecting statistically significant results for clinically relevant outcome differences. ${ }^{34}$

Following the extraction of the four first premolars, the effects of incisor retraction showed statistically significant changesin most soft tissue parameters (Table 1). However, most of these differences were less than $2 \mathrm{~mm}$ or $2^{\circ}$, hence not considered clinically significant. Clinically significant differences were found in the changes of horizontal position of the upper lip sulcus (SS-VRL) and upper lip (Ls-VRL), in addition to the nasolabial and mentolabial angles. These finding were in general agreement with the published literature evaluating the effect of premolar extraction on the soft tissue profile, ${ }^{5,8,10,12,13,15,35}$ but there are differences in the amount of change among the different studies. 
In the present study, the upper and lower lips showed backward movement of $1.52 \mathrm{~mm}$ and $0.76 \mathrm{~mm}$ relative to the E-line,respectively following premolar extraction. Comparable findings were reported by Kocadereli ${ }^{3}$ who reported $1.0 \mathrm{~mm}$ and $1.1 \mathrm{~mm}$ retraction of the upper and lower lips, respectively relative to the E-line. Similarly, Kinzinger et al. ${ }^{36}$ reported upper and lower lips posterior movement of $0.75 \mathrm{~mm}$ to the E-line following premolar extraction. On the other hand, considerable variations of the amount of lip retraction following premolar extraction have been reported in other studies. Bishara et al. ${ }^{4}$ found more backward movement with the upper lip moving $3.7 \mathrm{~mm}$ and the lower lip moving 3.4 $\mathrm{mm}$ posterior to the E-line. Bravo ${ }^{35}$ found similar amount of retraction of the upper and lower lips; $3.4 \mathrm{~mm}$ and $3.8 \mathrm{~mm}$ respectively, relative to the E-line. Also, Luecke and Johnston ${ }^{37}$ reported $2.4 \mathrm{~mm}$ posterior movement of the upper lip and $1.4 \mathrm{~mm}$ posterior movement of the lower lip to the E-line.

Nevertheless, it has to be stated that concordance between premolar extraction studies is lacking regarding both the magnitude of change in the position of the lips and its correlation to the movement of the upper and lower incisors. Owing to the large variations reported in the change of soft tissue profile following tooth movement, efforts to define such changes using mathematical equations seems futile. ${ }^{7}$ Collectively, all of the studies indicate a high degree of individual variability between upper and lower incisor retraction to upper and lower lip retraction. These dissimilarities in the findings of the amounts of lip retraction have been accredited to numerous aspects, among these; mechanics and anchorage devices used, softtissue thickness, ${ }^{38,39}$ labial tension at the beginning of treatment, ${ }^{8,39}$ and facial height ${ }^{9}$. Other variables that may affect lip response to orthodontic treatment include; weight gain or loss during treatment, disparities in adipose or muscle tissue amounts existing in the lips, lip-tooth contact area, and length of the lips. ${ }^{6}$ These various factors may have contributed to the wide variation of results observed. Therefore, it would be rational to observe the results cautiously, given the relevant data for each study separately.

Variations in the soft tissue changes previously discussed will consequently affect the ratios of and correlations between incisor retraction and lip retraction. In the present study, the mean ratio of upper incisor retraction to upper lip retraction was found to be $1.04: 1$ with a strong correlation of 0.812 (Table 2). This is interpreted as: $1 \mathrm{~mm}$ of upper incisor retraction will yield about $1 \mathrm{~mm}$ backward movement of the upper lip. The greater amount of lip retraction compared to incisor movement disagrees with a number of studies that reported less upper lip movement compared to incisor retraction. ${ }^{5-8,10,40}$ This may be attributed to the difference in the pretreatment characteristics of the treatment samples. Oliver ${ }^{38}$ found a stronger correlation between upper lip retraction and upper incisor retraction in patients with thin lips compared to those with thick upper lips. Incidentally, Celikoglu et al. ${ }^{41}$ reported that lower anterior facial soft tissue thickness values including the lips, were the lowest in the hyperdivergent skeletal pattern. This may explain the increased amount of lip retraction compared to incisor movement found in this study. Another possible explanation to the increased lip response is the reduced muscle tone witnessed in open bite subjects. ${ }^{42}$

In this study, the retraction of the mandibular incisor had a strong correlation to the retraction of the lower lip ( $r=0.802)$ with a mean ratio of 0.76:1. Comparable values were reported by Kasai ${ }^{7}$ (0.8:1), while Roos ${ }^{5}$ along with Caplan and Shivapuja ${ }^{8}$ reported mean ratios of $1.1: 1$ and $1.2: 1$, respectively. In the present study the lower lip was retracted to a greater extent than the lower incisor. This may be attributed to the changes in the tonicity of the lower lip as it continues to adapt to the reduction in the interlabial gap resulting from the reduction of facial height brought about by posterior segment intrusion. However, it is important to interpret this ratio in the light that the treatment required minimal retraction of the lower incisors which would undermine the extrapolation of this ratio to other situations 
where the lower incisors are significantly retracted.

Our findings show strong positive correlations between the amount of retraction of the upper and lower incisors each to the respective lip. Similarly, Rudee ${ }^{40}$ reported a high correlation for both the upper lip response $(r=0.73)$ and lower lip response $(r=0.70)$ to upper and lower incisor retractions, respectively. In addition, Scott Conley and Jernigan ${ }^{10}$ found a strong correlation $(r=0.75)$ between the maxillary incisor retraction and labralesuperius projection. However, other studies ${ }^{5,8}$ have shown a greater correlation between the lower incisor retraction to lower lip retraction than upper incisor retraction to upper lip retraction.

It is worth noting that the correlation coefficients of the ratios in this report were approximately 0.8 , hence the prediction ability of these ratios will be $64 \%$. Linear regression equations may offer a more accurate predictor rather than the mean ratios as has been shown in other studies. ${ }^{43,44}$

\section{CONCLUSION}

Following premolar extraction, both the upper and lower lips moved backward, increased in length and thickness, reducing both the interlabial gap and the soft tissue convexity even further.The direction of change appears to follow that reported in premolar extraction studies without prior molar intrusion. However, ratios of change of lip movement to incisor movement were comparatively higher compared to studies of lip response following premolar extraction without prior molar intrusion which may be attributed to the pretreatment long face skeletal pattern. Mean ratios and linear regression equations can be a clinical tool for predicting the change in soft tissue when premolar extraction is used with maxillary molar intrusion in long face subjects.

\section{REFERENCES}

1. Case CS. The question of extraction in orthodontia. Am J of Orthod. 1964;50: 660-91.
2. Sarver DM, Proffit WR. Special considerations in diagnosis and treatment planning. In: Graber TM, Vanarsdall RL, Vig KWL, editors. Orthodontics: Current principles and techniques. 4th ed. St. Louis, Missouri: Elsevier Health Sciences; 2005. p. 3-70.

3. Kocadereli I. Changes in soft tissue profile after orthodontic treatment with and without extractions. Am J Orthod Dentofacial Orthop. 2002;122:67-72.

4. Bishara SE, Cummins DM, Jakobsen JR, Zaher AR. Dentofacial and soft tissue changes in Class II, division 1 cases treated with and without extractions. Am J Orthod Dentofacial Orthop. 1995;107:28-37.

5. Roos N. Soft-tissue profile changes in class II treatment. Am J Orthod. 1977;72:165-75.

6. Perkins RA, Staley RN. Change in lip vermilion height during orthodontic treatment. Am J Orthod Dentofacial Orthop. 1993;103: 147-54.

7. Kasai K. Soft tissue adaptability to hard tissues in facial profiles. Am J Orthod Dentofacial Orthop. 1998;113:674-84.

8. Caplan MJ, Shivapuja PK. The effect of premolar extractions on the soft-tissue profile in adult African American females. Angle Orthod. 1997;67:129-36.

9. Hayasaki SM, Castanha Henriques JF, Janson G, de Freitas MR. Influence of extraction and nonextraction orthodontic treatment in Japanese-Brazilians with Class I and Class II division 1 malocclusions. Am J Orthod Dentofacial Orthop. 2005;127:30-6.

10. Scott Conley R, Jernigan C. Soft tissue changes after upper premolar extraction in Class II camouflage therapy. Angle Orthod. 2006;76:59-65.

11. Lim HJ, Ko KT, Hwang HS. Esthetic impact of premolar extraction and nonextraction treatments on Korean borderline patients. Am J Orthod Dentofacial Orthop. 2008;133:524-31.

12. Kusnoto J, Kusnoto H. The effect of anterior tooth retraction on lip position of orthodontically treated adult Indonesians. Am J Orthod Dentofacial Orthop. 2001;120:304-7.

13. Weyrich C, Lisson JA. The effect of premolar extractions on incisor position and soft tissue profile in patients with Class II, Division 1 malocclusion. J Orofac Orthop. 2009;70:128-38. 


\section{Egyptian \\ Orthodontic Journal}

14. Luppanapornlarp S, Johnston LE Jr. The effects of premolar-extraction: a long-term comparison of outcomes in "clear-cut" extraction and nonextraction Class II patients. Angle Orthod. 1993;63:257-72.

15. Zierhut EC, Joondeph DR, Artun J, Little RM. Long-term profile changes associated with successfully treated extraction and nonextraction Class II Division 1 malocclusions. Angle Orthod. 2000;70:208-19.

16. Maetevorakul S, Viteporn S. Factors influencing soft tissue profile changes following orthodontic treatment in patients with Class II Division 1 malocclusion. Prog Orthod. 2016;17:13.

17. Epker BN, Fish L. Surgical-orthodontic correction of open-bite deformity. Am J Orthod. 1977;71:278-99.

18. Hoppenreijs TJ, Freihofer HP, Stoelinga PJ, Tuinzing DB, van't Hof MA, van der Linden FP, et al. Skeletal and dento-alveolar stability of Le Fort I intrusion osteotomies and bimaxillary osteotomies in anterior open bite deformities. A retrospective three-centre study. Int J Oral Maxillofac Surg. 1997;26:161-75.

19. Proffit WR, Bailey LJ, Phillips C, Turvey TA. Long-term stability of surgical open-bite correction by Le Fort I osteotomy. Angle Orthod. 2000;70:112-7.

20. Sugawara J, Baik UB, Umemori M, Takahashi I, Nagasaka H, Kawamura H, et al. Treatment and posttreatment dentoalveolar changes following intrusion of mandibular molars with application of a skeletal anchorage system (SAS) for open bite correction. Int J Adult Orthodon Orthognath Surg. 2002;17:243-53.

21. Sherwood KH, Burch JG, Thompson WJ. Closing anterior open bites by intruding molars with titanium miniplate anchorage. Am J Orthod Dentofacial Orthop. 2002;122:593-600.

22. Erverdi N, Keles A, Nanda R. The use of skeletal anchorage in open bite treatment: a cephalometric evaluation. Angle Orthod. 2004;74:381-90.

23. Erverdi N, Usumez S, Solak A. New generation open-bite treatment with zygomatic anchorage. Angle Orthod. 2006;76:519-26.

24. Park HS, Kwon OW, Sung JH. Nonextraction treatment of an open bite with microscrew implant anchorage. Am J Orthod Dentofacial Orthop. 2006;130:391-402.
25. Xun C, Zeng X, Wang X. Microscrew anchorage in skeletal anterior open-bite treatment. Angle Orthod. 2007;77:47-56.

26. Scheffler NR, Proffit WR, Phillips C. Outcomes and stability in patients with anterior open bite and long anterior face height treated with temporary anchorage devices and a maxillary intrusion splint. Am J Orthod Dentofacial Orthop. 2014;146:594-602.

27. Deguchi T, Kurosaka H, Oikawa H, Kuroda S, Takahashi I, Yamashiro T, et al. Comparison of orthodontic treatment outcomes in adults with skeletal open bite between conventional edgewise treatment and implant-anchored orthodontics. Am J Orthod Dentofacial Orthop. 2011;139:S60-8.

28. Marzouk ES, Abdallah EM, El-Kenany WA. Molar intrusion in open-bite adults using zygomatic miniplates. Int J Orthod Milwaukee. 2015;26:47-54.

29. Marzouk ES, Kassem HE. Evaluation of longterm stability of skeletal anterior open bite correction in adults treated with maxillary posterior segment intrusion using zygomatic miniplates. Am J Orthod Dentofacial Orthop. 2016;150:78-88.

30. Alsafadi AS, Alabdullah MM, Saltaji H, Abdo A, Youssef M. Effect of molar intrusion with temporary anchorage devices in patients with anterior open bite: a systematic review. Prog Orthod. 2016;17:9.

31. Burstone CJ, James RB, Legan H, Murphy GA, Norton LA. Cephalometrics for orthognathic surgery. J Oral Surg. 1978;36:269-77.

32. Burstone CJ. Lip posture and its significance in treatment planning. Am J Orthod. 1967;53:262-84.

33. Dolphin Imaging \& Management Solutions [Internet]. Patterson Dental Supply, Inc.; 2018. Available from:https://www.dolphinimaging. com/product/Imaging?Subcategory_OS_Safe _Name=Treatment_Simulation\&Feature_OS _Safe_Name=VTO_Wizards_and_Analysis

34. Proffit WR. EVIDENCE AND CLINICAL DECISIONS: Asking the Right Questions to Obtain Clinically Useful Answers. Semin Orthod. 2013;19. 
35. Bravo LA. Soft tissue facial profile changes after orthodontic treatment with four premolars extracted. Angle Orthod. 1994;64:31-42.

36. Kinzinger G, Frye L, Diedrich P. Class II treatment in adults: comparing camouflage orthodontics, dentofacial orthopedics and orthognathic surgery--a cephalometric study to evaluate various therapeutic effects. J Orofac Orthop. 2009;70:63-91.

37. Luecke PE 3rd, Johnston LE Jr. The effect of maxillary first premolar extraction and incisor retraction on mandibular position: testing the central dogma of "functional orthodontics". Am J Orthod Dentofacial Orthop. 1992;101:4-12.

38. Oliver BM. The influence of lip thickness and strain on upper lip response to incisor retraction. Am J Orthod. 1982;82:141-9.

39. Angelle PL. A cephalometric study of the soft tissue changes during and after orthodontic treatment. Trans Eur Orthod Soc. 1973:267-80.
40. Rudee DA. Proportional profile changes concurrent with orthodontic therapy. Am J Orthod. 1964;50:421-34.

41. Celikoglu M, Buyuk SK, Ekizer A, Sekerci AE, Sisman Y. Assessment of the soft tissue thickness at the lower anterior face in adult patients with different skeletal vertical patterns using cone-beam computed tomography. Angle Orthod. 2015;85:211-7.

42. Piancino MG, Isola G, Merlo A, Dalessandri D, Debernardi C, Bracco P. Chewing pattern and muscular activation in open bite patients. $\mathrm{J}$ Electromyogr Kinesiol. 2012;22:273-9.

43. Shirvani A, Sadeghian S, Abbasi S. Prediction of lip response to orthodontic treatment using a multivariable regression model. Dent Res J (Isfahan). 2016;13:38-45.

44. Denis KL, Speidel TM. Comparison of three methods of profile change prediction in the adult orthodontic patient. Am J Orthod Dentofacial Orthop. 1987;92:396-402. 